Volume 2 No. 2, Desember 2017

P ISSN 2442-594X | E ISSN 2579-5708

http://journal.iainlangsa.ac.id/index.php/tibyan

\title{
HERMENEUTIKA SEBAGAI METODE BARU DALAM MENAFSIRKAN ALQURAN
}

\author{
Hermeneutics As A New's Method in The Qur'anic's Interpretation
}

\author{
Mulizar \\ Institut Agama Islam Negeri Langsa \\ izar_fajar@yahoo.com
}

\begin{abstract}
This article will discuss hermeneutics as a new method of interpreting the Qur'an.The use of hermeneutics is a new thingin the world of interpretation. Some support and some reject it.The results of this study show that the use of hermeneutics in interpreting the Qur'an must be careful.In addition, This science should be placed as a complement, not as a subdivision of the science of interpretation. On the other hand, hermeneutics paves the way to contextualize the scriptures, so that they can dialogue in different spaces and times, as apologically desirable and held by many religious groups to their respective scriptures.
\end{abstract}

Keywords:Hermeneutika, teks, Konteks, Kontektual.

\begin{abstract}
Abstrak
Artikel ini akan membahas tentang hermeneutika sebagai motode baru dalam menafsirkan Alquran. Penggunaan hermeneutika dalam duniatafsir adalah hal baru,sehingga menimbulkan polemik. Sebagian mendukung dansebagian lagi menolaknya.Hasilkajian pada masalah ini, menunjukkan bahwa penggunaan hermeneutika dalampenafsiran ayat-ayat Alquran haruslah hati-hati.Selain itu pula ilmu inisebaiknya ditempatkan sebagai komplemen, bukannya sublemen dari ilmu tafsir. Di sisi lain, hermeneutikamembuka jalan bagi upaya kontekstualisasi kitab suci sehingga dapat berdialog dan operasionalfungsional dalam berbagai ruang dan waktuyang berbeda, sebagaimana yang diidamkan dan dipegangi secara apologisoleh banyak kalangan Umat beragama terhadap kitab sucinya masingmasing.
\end{abstract}

Kata Kunci: Hermeneutika, teks, Konteks, Kontektual. 


\section{Pendahuluan}

Kitab Alquran yang merupakan bukti kebenaran Nabi Muhammad saw., sekaligus petunjuk bagi manusia ini, memiliki berbagai keistimewaan. Keistimewaan tersebut antara lain: susunan bahasanya yang unik dan memesonakan, sifat agung yang tidak seorangpun mampu mendatangkan hal serupa, bentuk undang-undang yang komprehensif melebihi undang-undang karya cipta manusia, memuat pengetahuan yang tidak bertentangan dengan pengetahuan umum dan dipastikan kebenarannya. Alquran merupakan teks rasional yang membuka banyak jalan untuk ditafsirkan. Keberagaman hasil penafsiran tersebut dibarengi dengan latar belakang dan kebutuhan yang berbeda dari setiap penafsir, disamping tingkatan pengetahuan masing-masing penafsir yang berbeda-beda dan sangat bervariasi.Sebagai sebuah ideal yang diletakkan dalam posisi tertinggi oleh 'komunitas' umat Islam, tidak berlebihan apabila Alquran dicita-citakansebagai 'pengkondisi' tertinggi bagi proses bernalar setiap muslim. Dalamrealitas sejarahnya, ideal Alquran sebagai sumber inspirasi dan kreatifitasberpikir umat Islam dapat dikatakan telah dan pernah terjadi, setidaknyasejak masa Nabi sampai sekitar abad pertengahan.Berbagai disiplin keilmuan mulai dari kedokteransampai filsafat yang muncul pada periode ini dapat dikatakan merupakan manifestasi dari aktifitas kreatif-intelektual yangmeskipun bergerak dalam berbagai wilayah kehidupan kontekstual saat itu tidak sertamerta meninggalkan Alquran, namun justru bertolak atau setidaknyamengambil inspirasi serta tunt unan dasar dari Alquran.

Namun dalam realitas kekiniannya, ideal yang dicita-citakan tersebutmulai memudar. Berbagai interaksi dan pergumulan ilmiah, sosial, politikdan budaya yang dialami Umat Islam pada saat ini menunjukkan tanda-tanda betapa ideal tersebut semakin jauh dari jangkauan. Apabila dicermati, kondisi semacam ini tampak dalam dua aspek: Pertama, munculnya gaya berpikir 'ikut-ikutan' (taklid) dari sebagian besar umat Islam, sehingga Alquran tidak lagi menjadi ideal tertinggi, tetapi yang menjadi ideal tertinggi adalah hasil pemikiran dan pemahaman umat Islam sebelumnya yang disakralkan dan diberi label "tidak boleh dipertanyakan". Dalam istilahArkoun hal semacam ini disebut "Taqdis al-Afkar al-Diniyyah".Kedua, beberapa kalangan Umat Islam yang terdidik merasa at home dengan berbagai ideal lain selain Alquran, sehingga dalam pandangan mereka ini, untukbisa maju Umat Islam harus sekali-sekali 'berani' membuat 'terobosanbaru' dan jangan terlalu terikat dengan isi dan pesan alquran.Kedua sikap ini pada akhirnya jelas akan membawa satu dampakbesar: Alquran menjadi asing dan tidak lagi operasionalfungsional dalamkehidupan Umat Islam. Sebagai respon atas kondisi yang menggelisahkanini, tidak mengherankan jika kemudian beberapa waktu yang lalu muncul isu-isu besar seperti Kontekstualisasi, Reaktualisasi, Rekonstruksi dan juga Pembumian Alquran. Pesan utama dari isu-isu baru tersebut secara umum adalah tuntutan agar Alquran juga dapat berfungsi 'operatif' diera kekinian dengan episteme yang tidak lagi sama dengan 'dulu'. Akhirakhir ini di kalangan kaum muslimin terutama kaum modernistelah banyak 
memanfaatkan Hermeneutika sebagai salah satu instrumen untuk menggali isi dan kandungan Alquran. Penggunaan ilmu tersebut dalam penafsiran alquran ada yang menempatkannya sebagai komplemen dan ada pula yang menempatkannya sebagai sublemen.Penggunaan hermeneutika dalam dunia penafsiran Alquran adalah hal baru yang belum pernah dilakukan oleh para mufassir terdahulu. Dalam tradisi keilmuwan Islam telah dikenal ilmu tafsir yang berfungsi untuk menafsirkan Alquran, sehingga ilmu ini dianggap telah mapan dalam bidangnya. Dari segi epistemologi dan metodologi ilmu ini telah diakui mampu mengembankan tugasnya untuk menggali kandungan alquran. Penggunaan Hermeneutika dalam penafsiran ayat-ayat alquran mendapat tanggapan yang beragam dari para ulama dan cendekiawan muslim. Ada yang menyetujuinya dan ada pula yang menolaknya. Pada awal abad ke-20 beberapa mufassir seperti Muhammad Abduh dalam tafsirnya al-Manar telah menggunakan ilmu ini dalam praktek penafsiran ayat-ayat alquran, yang walaupun dia belum secara eksplisit memproklamirkan penggunaan Hermeneutika dalam penafsiran. Penggunaan ilmu ini secara terang-terangan baru dilakukan pada tahun tujuh puluhan abad 20 .

\section{Pemahaman Hermeneutika}

Sebelum lebih jauh berbicara tentang interpretasi alquran via Hermeunetika, maka terlebih dahulu harus memahami dari definisi hermeneutik itu sendiri. Hermeneutika berasal dari bahasa Yunani, yaitu dari akar kata hermeneuin yang berarti menafsirkan. Hermeneutika sebagai seni menafsirkan mengharuskan tiga komponen, yakni teks, penafsir dan penyampaian kepada pendengar. Hermeneutika berperan menjelaskan teks seperti apa yang diinginkan oleh si pembuat teks tersebut. ${ }^{1}$ Menurut Komaruddin Hidayat, kata Hermeneutika pada mulanya merujuk pada nama dewa Yunani Kuno, Hermes yang tugasnya menyampaikan berita dari Sang Maha Dewa yang dialamatkan kepada manusia. ${ }^{2}$ Husein Nashr berpendapat bahwa Hermes tak lain adalah nabi Idris As. yang disebutkan dalam alquran. Dalam legenda yang beredar di kalangan pesantren pekerjaan nabi Idris adalah sebagai tukang tenun. Jika profesi tukang tenun dikaitkan dengan mitos Yunani tentang peran Dewa Hermes, ternyata ada korelasi positif. Kata kerja memintal padanannya dalam bahasa latin adalah tegere, sedangkan produknya disebut textus atau text yang merupakan isu sentral dalam hermeneutika.

Hermeneutika pada dasarnya adalah suatu metode atau cara untuk menafsirkan simbol yang berupa teks atau sesuatu yang diperlakukansebagai teks untuk dicari arti dan maknanya, dimana metode hermeneutik ini mensyaratkan adanya kemampuan untuk menafsirkan masa lampau yang tidak dialami, kemudian dibawa ke masa sekarang. ${ }^{3}$ Beberapa tahun terakhir ini, kajian-kajian mengenai Hermeneutika maupun kajian-kajian yang memanfaatkan Hermeneutika sebagai pendekatan semakin

${ }^{1}$ Mircea Eliade,The Encyclopedia of Religion, (New York: Macmillan, 1993), h. 279.

${ }^{2}$ Komaruddin Hidayat,Memahami Bahasa Agama: Sebuah Kajian Hermeneutika,(Jakarta: Paramadina, 1996), h.125.

${ }^{3}$ Sudarto, Metodologi Penelitian Filsafat, (Jakarta: PT. Raja Grafindo Persada, 1996), h.85. 
"populer" dan dipakai oleh berbagai ilmuwan dari berbagai bidang kajian seperti para kritikus sastra, sosiolog, sejarawan, antropolog, filosof, termasuk juga para pengkaji agama-agama. Meski Hermeneutika bisa dipakai sebagai alat untuk "menafsirkan" berbagai bidang kajian keilmuan, melihat sejarah kelahiran dan perkembangannya, harus diakui bahwa peran Hermeneutika yang palingbesar adalah dalam bidang ilmu sejarah dan kritik teks, khususnya kitab suci. Mengenai hal ini Roger Trigg, sebagaimana dikutip oleh KomaruddinHidayat dalam bukunya Memahami Bahasa Agama berkata: ${ }^{4}$ The Paradigm for hermeneutics is the interpretation of a traditionaltext, where the problem must always be how we can come tounderstand in our own context something which was written in aradically different situation.

Hasan Hanafi dalam tulisannya Religious Dialogue andRevolution menyatakan bahwa Hermeneutik itu tidak sekedar ilmu interpretasi atau teori pemahaman, tetapi juga berarti ilmu yang menjelaskan penerimaanwahyu sejak dari tingkat perkataan sampai ke tingkat dunia. Ilmu tentangproses wahyu dari huruf sampai kenyataan, dari logos sampai praksis danjuga transformasi wahyu dari pikiran Tuhan kepada kehidupan manusia. ${ }^{5}$ Tidak mengherankan apabila Hermeneutika juga menarik minat parailmuwan agama karena bisa dikatakan problema Hermeneutik ini sangaterat berkaitan dengan kajian keagamaan; baik dalam aspek konseptualmaupun dalam aspek historis.Secara konseptual, agama sendiri bisa dikatakan sebagai "komunitas tafsir", sehingga kajian terhadap agama itu pada dasarnya adalah penafsiran terhadap tafsir.Sementara secarahistoris, agama merepresentasikan adanya keragaman penafsiran manusiayang sangat erat berkaitan dengan latar belakang historis masing-masingpandangan. ${ }^{6}$

Salah satu bidang kajian agama yang paling dekat denganHermeneutika adalah kitab suci, karena HermeneutikakhususnyaHermeneutika moderen pada awal perkembangannya muncul sebagaisatu metode untuk memahami kitab suci. Persoalan yang sering dihadapi berkait dengan Hermeneutika dan kitab suci ini antara lain adalahbagaimana teks kitab suci mampu berbicara dengan generasi yang datangsetelah teks itu lahir?, bagaimana teks kitab suci itu bisa operasionaldan fungsional dalam masyarakat yang berbeda corak hidup dan kulturbudayanya dengan masyarakat saat teks tersebut lahir?, bisakah pesan teksitu disampaikan tanpa mengalami distorsi dan penyimpangan makna?, danlain sebagainya.Istilah Hermeneutik sendiri dalam sejarah keilmuan Islam, khususnyatafsir Al-Qur'an klasik, memang tidak ditemukan. Istilah tersebutkalaumelihat sejarah perkembangan Hermeneutika Moderenpopuler ketikaIslam justru dalam masa kemunduran. Meski demikian, menurut FaridEsack dalam bukunya Qur'an: Liberation and Pluralism, praktek Hermeneutiksebenarnya telah dilakukan oleh Umat Islam sejak lama, khususnya ketikamenghadapi Alquran. Bukti dari hal itu adalah:

\footnotetext{
${ }^{4}$ Komaruddin Hidayat, Memahami Bahasa Agama, (Jakarta:Paramadina,1996), h. 161.

${ }^{5}$ Hasan Hanafi, Dialog Agama dan Revolusi, terj. Pustaka Firdaus, (Jakarta: Pustaka Firdaus,1994), h. 1.

${ }^{6}$ Van A. Harvey, "Hermeneutics" dalam Eliade, Mircea (ed.), Encyclopedia of Religion, (London: MacMillan, 1986), h. 80.
} 
a. Problematika Hermeneutik itu senantiasa dialami dan dikaji, meskitidak ditampilkan secara definitif. Hal ini terbukti dari kajian-kajianmengenai asbabunnuzul dan nasakh-mansukh.

b. Perbedaan antara komentar-komentar yang aktual terhadap Alquran(tafsir) dengan aturan, teori atau metode penafsiran telah ada sejakmulai munculnya literaturliteratur tafsir yang disusun dalam bentukilmu tafsir.

c. Tafsir tradisional itu selalu dimasukkan dalam kategori-kategori,misalnya tafsir syi'ah, tafsir mu'tazilah, tafsir hukum, tafsir filsafat, danlain sebagainya. Hal itu menunjukkan adanya kelompok-kelompoktertentu, ideologi-ideologi tertentu, periode-periode tertentu, maupunhorison-horison sosial tertentu dari tafsir. ${ }^{7}$

Operasional Hermeneutika Moderen dalam penafsiran Alquran bisa dikatakan dirintis oleh para pembaharu muslim; seperti di Indiadikenal Ahmad Khan, Amir Ali dan Ghulam Ahmad Parves, yang berusahamelakukan demitologisasi, ${ }^{8}$ konsep-konsep dalam Alquran yang dianggapbersifat mitologis, seperti mengenai mukjizat dan hal-hal gaib. Di Mesirmuncul Muhammad Abduh yang secara rasional melakukan operasiHermeneutik dengan bertumpu pada analisis sosial-kemasyarakatan.Meskipun demikian, rumusan metodologis mereka ini tidak sistematis danjelas.Dalam dekade 1960 sampai 1970-an, muncul tokoh-tokoh yang mulai serius memikirkan persoalan metodologi tafsir ini.Hassan Hanafimempublikasikan tiga karyanya yang bercorak Hermeneutik; yang pertamaberkaitan dengan upaya rekonstruksi ilmu ushul fiqih, yang kedua berkaitandengan Hermeneutika fenomenologis dalam menafsirkan fenomenakeagamaan dan keberagamaan, dan yang ketiga berhubungan dengankajian kritis terhadap Hermeneutika eksistensial dalam kerangka penafsiranPerjanjian Baru. ${ }^{9}$

Dewasa ini telah banyak pemerhati Alquran yang melakukan kritikhistoris dan linguistik yang menjadi ciri khas Hermeneutika.Tulisan-tulisanyang menyangkut bidang ini banyak bermunculan, baik dari kalanganoutsider maupun dari kalangan Umat Islam sendiri. Diantara tulisan-tulisantersebut misalnya Qur'anic Hermeneutic: The Views of al-Tabari and Ibn katsirkarya Jane Mc Auliffe yang menekankan pada metode tafsirnya dan sedikitpada horison sosialnya, ${ }^{10}$ lalu tulisan Azim Nandji yang membahas tentangteori ta'wil dalam tradisi keilmuan Isma'ili yang banyak membantu dalamkritik sastra, ${ }^{11}$ juga Nasr Hamid Abu Zayd yang dengan intensif

\footnotetext{
${ }^{7}$ Farid Esack, Qur'an: Liberation \& Pluralism (Oxford: One World, 1997), h. 161.

${ }^{8}$ Demitologisasi disini bukan berarti membuang sama sekali cerita-cerita yang dianggapmitos karena dianggap sekedar dongeng-dongeng, tetapi berarti mempersepsikan mitos sebagaiungkapan simbolis mengenai satu realitas dengan mempergunakan gambaran-gambaran, kiasankiasandan lukisan-lukisan. Dengan demikian persoalannya bukanlah bagaimana melenyapkan mitos tetapi bagaimana menafsirkannya secara eksistensial.

${ }^{9}$ Hassan Hanafi, Muqaddimah fi 'Ilm al-Istighrab, (Kairo: Dar al-Faniyah, 1991), h. 8486.

${ }^{10}$ Lihat Jane Mc Mauliffe, “Qur'anic Hermeneutics: The Views of Al-tabari and The Ibn Katsir” dalam A. Rippin (ed.), Approaches to the History of the Qur'an, (Oxford: Clarendon, 1988),h. 46-62.

${ }^{11}$ Azim Nanji, “Toward a Hermeneutic of Qur'anic and Other Narratives of Isma'iliThought" dalam Richard C.martin (ed.), Approaches to Islam in Religious Studies (Tucson: TheUniversity of Arizona Press), h.164-174.
} 
menggelutikajian Hermeneutik. ${ }^{12}$ Mohammed Arkoun dari Aljazair menelurkan idenya mengenai cara baca semiotik terhadap Alquran, dan Fazlurrahman merumuskan metode Hermeneutika yang sistematik terhadap Alquransekaligus mempraktekkannya.

Sehubungan dengan pendekatan hermeneutika moderen terhadapAlquran ini, maka perlu diperhatikan tiga hal yang menjadi asumsi dasardalam penafsirannya, yaitu:

\section{Manusia Salah Satu Penafsir}

Setiap generasi muslim sejak masa NabiMuhammad, sambil membawa "muatan"nya itu, telah memproduksikomentar-komentar mereka sendiri terhadap Alquran. Tidaklahmengherankan jika akhirnya ada beragam interpretasi dari setiapgenerasi. ${ }^{13}$ Siapapun orangnya yang menafsirkan teks kitab suci itu, ia tetaplah manusia biasa yang lengkap dengan segala kekurangan, kelebihannya dan kesementaraannya karena terikat oleh ruang dan waktu tertentu. Dengan asumsi ini diharapkan bisa dimengerti bahwasanya manusia itu tidak akanbisa melepaskan diri dari ikatan historis kehidupan dan pengalamannya, dimana ikatan tersebut sedikit banyak akan membawa pengaruh danmewarnai corak penafsirannya. Asumsi ini dimaksudkan untuk tidakmemberikan vonis "mutlak" benar atau salah kepada suatu penafsiran, namun lebih mengarah untuk melakukan pemahaman dan analisa yang kritis terhadap satu penafsiran. Para penafsir adalah manusia yang membawa "muatanmuatan" kemanusiaan masing-masing.

\section{Interpretasi Tidak Dapat Terlepas Dari Unsur Bahasa, Sejarah dan Tradisi.}

Pergulatan Umat Islam denganAlquran juga berada dalam "kurungan" ini. Seseorang tidak mungkinbisa melepaskan diri dari bahasa, budaya dan tradisi dimana mereka hidup.Aktifitas penafsiran pada dasarnya merupakan satu partisipasi dalam proses historislinguistik dan tradisi yang berlaku, dimana partisipasiini terjadi dalam ruang dan waktu tertentu.Para pemikir reformis sering menyatakan bahwasanya krisis yang terjadidi dunia Islam serta ketidak mampuan umat Islam untuk memberikansatu kontribusi yang berguna bagi dunia kontemporer adalah dikarenakantradisi. Jalan keluar yang dianjurkan oleh para reformis itu seringkali adalahdengan meninggalkan ikatan tradisi dan "kembali kepada Alquran".Pernyataan tersebut sebenarnya tidak selaras dengan fakta bahwasanya satu penafsiran itu tidak bisa secara sepenuhnya mandiri berdasarkan teks,tetapi pasti terkait dengan muatan historisnya, baik muatan historis saatteks itu muncul dan saat teks itu ditafsirkan. ${ }^{14}$

\footnotetext{
${ }^{12}$ Nasr Hamid Abu Zayd, Isykaliyat al-Qira'at wa 'Aliyat al-Ta'wil(Beirut: al-Markaz al-Saqafi al'Arabi, 1994)

${ }^{13}$ Farid Esack, Qur'an Pluralism and Liberation, h. 50.

${ }^{14}$ Ibid., h. 77.
} 


\section{Teks yang menjadi wilayah bagi dirinya sendiri.}

Sosiohistoris dan linguistik dalam pewahyuan Alquran itu nampak dalam isi, bentuk, tujuan dan bahasa yang dipakai Alquran.Halini nampak pula misalnya dalam pembedaan antara ayat-ayat makkiyah dan ayat-ayat madaniyah. Dalam hubungannya dengan proses pewahyuan, bahasa dan isi di satu sisi; serta dengan komunitas masyarakat yang menerimanyadi sisi yang lain, Alquran tidaklah "unik". Wahyu selalu saja merupakankomentar terhadapsetidaknya harus dipahami dalam kerangkakondisimasyarakat tertentu dimana wahyu itu turun. ${ }^{15}$

\section{Historisasi Hermeneutika}

Istilah Hermeneutika untuk pertama kali dikemukakan oleh Aristoteles. Diapernah menulis sebuah buku berjudul Peri Hermeneias yang kemudian diterjemahkan ke dalam bahasa Latin dengan nama De Interpretatione yang dalam bahasa Inggrisnya berjudul On the Interpretation. Sebelum diterjemahkan ke dalam bahasa Latin dan Inggris, salah seorang filosof Islam al Faraby (w.339/950) telah menterjemahkan dan memberi komentar karya Aristoteles tersebut ke dalam bahasa Arab dengan judul fil 'Ibarah. Konsep hermeneutika yang digunakan Aristoteles masih sangat sederhana, tidak sama dengan konsep yang digunakan sekarang ini. Hermeneias yang dia kemukakan sekedar membahas peranan ungkapan dalam memahami pemikiran dan membahas tentang satuan-satuan bahasa seperti kata benda (isim), kata kerja (fi'il), kalimat (jumlah), ungkapan (preposition) dan lain-lain yang terkait dengan bahasa. Ketika Aristoteles membicarakan hermenias, dia tidak mempermasalahkan teks atau membuat kritikan terhadap teks.Topik yang dibahas oleh Aristoteles adalah mengenai bidang interpretasi itu sendiri, tanpa mempersoalkan teks yang diinterpretasikan itu.Dalam perkembangan berikutnya pengertian Hermeneutika beralih dari makna leksikal kepada makna istilah.Perkembangan ke arah ini dimulai oleh para teolog Yahudi dan Kristen dalam mengkaji ulang secara kritis teks-teks dalam kitab suci mereka. Mereka menggunakan ini bertujuan untuk mencari kebenaran dari kitab suci mereka yang sangat beragam. Mereka mempertanyakan apakah secara harfiyah Bible itu bisa dianggap kalam Tuhan. Kitab Bible yang ada pada mereka sangat beragam antara karya yang satu dengan lainnya. Adanya perbedaan pengarang itulah yang menyebabkan Bible tidak bisa dikatakan kalam Tuhan. Oleh karena itu para teolog Kristen memerlukan Hermeneutika. Ketika perkembangan Hermeneutika dalam tradisi Barat masih pada tahap ini maka ia diposisikan sebagai bagian dari ilmu filologi. Oleh karenanya historiografi merupakan klien Hermeneutika yang paling setia. Memasuki akhir abad ke-18, Hermeneutika mulai dirasakan sebagai teman sekaligus tantangan bagi ilmu sosial, utamanya sejarah dan sosiologi, karena Hermeneutika mulai berbicara dan menggugat metode dan konsep ilmu sosial pada umumnya.Ketika era metafisika mulai berakhir, dan klaim sains modern dalam memonopoli ilmu pengetahuan mulai berkurang, maka mulailah dikembangkan universalitas yang murni

\footnotetext{
${ }^{15}$ Ibid.,h.33.
} 
didapatkan pada Hermeneutika. Maka pada zaman Romatis (1775-1830) Hermeneutika berkembang ke berbagai teori dan ilmu pengetahuan.Hermeneutika adalah ilmu yang membahas bagaimana menafsirkan sebuah teks. Ilmu ini berperan menjelaskan teks seperti apa yang diinginkan oleh si pembuat teks tersebut. Peran ini persis seperti figur Hermes yang bertugas membawakan pesan-pesan Tuhan Zeus kepada manusia. Karena pesan-pesan tersebut masih dalam bahasa langit, maka perlu perantara yang bisa menafsirkan dan menerjemahkannya ke dalam bahasa bumi. Dari fungsi dan peran inilah Hermeneutika mulai mendapatkan makna baru sebagai sains atau seni menafsir. $^{16}$

\section{Hermeneutical: Mengolah Teks, Melacak Makna}

Langkah awal yang tentunya tidak boleh diabaikan dalam penafsiran Alquran adalah memahami teksnya, yakni melihatnya dalam aspek kebahasannya, yaitu bahasa Arab. Tidak kurang dari sembilan kali Alquransendirimenyebutbahwaalatkomunikasi yang dipakainya adalahbahasa Arab. Hanya dengan terlebih dahulu memahami teks atau aspekkebahasaan inilah nantinya seorang penafsir bisa memahami baik makna,hikmah maupun hukum dari Alquran secara tepat. ${ }^{17}$ Hermeneutik pada asalnya berhubungan dengan bahasa; sementara kehidupan manusia tidak bisa dilepaskan dari bahasa. Manusia menulis, berpikir, memahami, berbicara dan lain sebagainya melalui bahasa. Tidak heran jika Gadamer menyebut bahwa bahasa merupakan modus operandidari keberadaan manusia di dunia dan merupakan wujud yang seakanakan meliputi seluruh konstitusi tentang dunia ini. ${ }^{18}$

Menurut M.A.S. Abdul Haleem dalam tulisannya yang berjudul Contextand Internal Relationships: keys to Qur'anic Exegesis, A Study of Surat Al-Rahman (Qur'an Chapter 55,) tanpa perhatian terhadap teks bisa dipastikan seorangpenafsir akan mendapatkan pengertian dan kesan yang salah sehingga penjelasannya terhadap ayat akan keliru atau setidaknya ia akan membuatkesimpulan yang tidak berdasar. ${ }^{19}$ Teks bisa diartikan sebagai himpunan huruf yang membentuk katadan kalimat yang dirangkai dengan sistem tanda yang disepakati olehmasyarakat. ${ }^{20}$ Teks adalah kandungan atau isi suatu naskah. ${ }^{21}$ Teks terdiri atasisi dan bentuk. Isi mengandung ideide atau amanat yang ingin disampaikan oleh 'pengarang' kepada pembaca; sedangkan bentuk merupakan muatan cerita atau pelajaran yang hendak dibaca dan dipelajari

\footnotetext{
${ }^{16}$ Malki Ahmad Nasir. 2004 "Hermeutika Kritis (Studi Kritis atas PemikiranHabermas)" dalam Jurnal Islamia Thn. I No.I Jakarta: Khairul Bayan.

${ }^{17}$ Lihat Al-Qur' an S. 13:37, 26:195, 12:2, 16:103, 39:28, 41:3, 42:7, 43:3 dan 46:12.

${ }^{18}$ E. Sumaryono, Hermeneutik, sebuah Metode Filsafat...,h. 26.

${ }^{19}$ M.A.S. Abdul Haleem, "Context and Internal Relationships: Keys to Qur'anic Exegesis,A Study of Surat Al-Rahman (Qur'an Chapter 55)" dalam G.R. Hawting and Abdul Kader A.Syareef, Approaches to the Qur'an (London and New York: Routledge, 1993), h. 71-98.

${ }^{20}$ Jos Daniel Parera, Leksikon Istilah Pembelajaran Bahasa, (Jakarta: PT. Gramedia PustakaUtama, 1993), h. 149.

${ }^{21}$ Nabilah Lubis, Naskah, Teks dan Metode Penelitian Filologi, (Jakarta: Forum Kajian Bahasadan Sastra Arab Fakultas Adab IAIN syarif Hidayatullah, 1996), h. 27.
} 
menurut berbagai pendekatan melalui alur, perwatakan, gaya dan lain sebagainya. ${ }^{22}$ Josef Bleicher dalam tulisannya Contemporary Hermeneutics menyatakan bahwa dalam hal menganalisis teks, Hermeneutika memiliki dua tugas, yaitu menemukan makna dari sebuah kata, kalimat atau frasa, dan menemukan petunjuk-petunjuk yang tersimpan dalam bentuk simbol. ${ }^{23}$ Pendapat Josef Bleicher tersebut agaknya senada dengan pandangan Nasr Hamid Abu Zayd terhadap Alquran, dimana menurut Abu Zayd, seorang penafsir diharuskan untuk mampu menemukan makna yang tersembunyi dalam teks dengan pertama-tama melakukan pembacaan teks secara analistis melalui kata-kata kunci dan ide-ide fundamental teks yang dikaji. ${ }^{24}$

Ketika teks Alquran dihadapkan pada "alat olah" Hermeneutik, maka teks Alquran akan diperlakukan sama sebagaimana teks-tekslainnya, dimana untuk memahaminya seseorang dituntut untuk mampu menangkap makna yang ada dalam teks tersebut dengan mempertimbangkan bagaimana teks tersebut dipahami oleh masyarakat dimana ia turun dan bagaimana teks tersebut harus dipahami dalam konteks yang berbedadalam upaya kontekstualisasi. Banyak ilmuwan muslim kontemporer yang mengkaji hal ini secara intensif. Fazlurrahman misalnya, ia menganggap bahwa Alquran pada dasarnya adalah respon ilahi melalui ingatan dan pikiran Nabi kepada situasi moral sosial Arab pada masa Nabi. ${ }^{25}$ Sementara itu bagi Farid Esack Alquran adalah sekumpulan firman Allah yang diturunkan sebagai wahyu untuk merespon tuntutan masyarakat masa Nabi selama 23 tahun. ${ }^{26}$ Sedangkan bagi Abu Zayd teks Alquran itu berawal dari realitas, dimanadari bahasa dan budaya realitas tersebut, dibentuklah konsepsi-konsepsi (mafahim)-nya, dan di tengah pergerakannya dengan interaksi manusia terbaharuilah makna (dalalah)-nya. ${ }^{27}$ Secara historis, mufassir Alquran yang mula-mula melakukan pendekatan pada aspek bahasa ini bisa dikatakan adalah Ibnu Abbas. Dalam tafsirnya, selain mendasarkan pada sunnah dan juga cerita-cerita Israiliyyat, Ibnu Abbas juga menggunakan syair-syair Arab pra-Islam sebagai acuan pencarian makna lafaz-lafaz Alquran. ${ }^{28}$ Mengenai kitabkitab tafsir yang menekankan aspek kebahasaan ini,John Wansbrough dalam kajiannya terhadap kitab-kitab tafsir Alquran klasik mengklasifikasi tafsir jenis ini menjadi dua, yaitu tafsir tekstual dan tafsir retorik. ${ }^{29}$ Penafsiran tekstual dalam menafsirkan terpusat pada pengkajian secara filologis dengan menjelaskan aspek-aspek leksikon dalam ragam bacaan ayat-ayat Alquran. Salah satu tafsir jenis ini adalah karya al-Farra'(w.

\footnotetext{
${ }^{22}$ Ibid.

${ }^{23}$ Josef Bleicher, Contemporary Hermeneutics, , h. 11.

${ }^{24}$ Nasr Hamid Abu Zayd, Isykaliyat al-Qira'at..., h. 13-17.

${ }^{25}$ Fazlurrahman, Islam dan Modernitas, terj. Ahsin Muhammad (Bandung: Pustaka, 1985),h.6.

${ }^{26}$ Farid Esack, Qur'an: Liberation and Pluralism,h. 53.

${ }^{27}$ Moch. Mur Ichwan, “Al-Qur'an sebagai Teks: Teori Teks dalam Hermeneutik Al-Qur'anNasr Abu Zayd" dalam Esensia, Vol. 2, No.1, 2001, h. 85.

${ }^{28}$ Jalal al-Din al-Suyuti, Al-Itqan fi 'Ulum Al-Qur'an (Beirut: Dar al-Fikr, t.t.), h. 113-114

${ }^{29}$ Lihat ringkasannya dalam Ihsan Ali Fauzi, "Kaum Muslimin dan Tafsir Al-Qur'an:Survey Bibliografis atas Karya-karya dalam Bahasa Arab” dalam Ulumul Qur'an, no.5, Vol.11, 1990, h. 15.
} 
822 H.) yang berjudul Ma'ani Al-Qur'an yang dengan intens berusahamenjelaskan beberapa kemusykilan gramatikal dan tekstual ayat-ayat AlQur'an. ${ }^{30}$

Penafsiran retorik merupakan perkembangan lebih jauh dari analisis linguistik, dimana pusat perhatiannya beralih kepada aspek kekhasanbahasa Alquran. Contoh tafsir jenis ini adalah Majaz Alquran karyaAbu 'Ubaydah (w. 824) dan Ta'wil Musykil Alquran karya Ibn Qutaybah(w. 889) yang menekankan persoalan i’jaz atau watak kemukjizatan Alqurandari aspek bahasanya.Pada akhirnya, "pengolahan" terhadap teks secara Hermeneutik dalam penafsiran Alquran ini semakin berkembang dan mengalami penyempurnaa-penyempurnaan, khususnya dilakukan oleh para ilmuwan kontemporer yang mahir dalam ilmu linguistik, seperti Toshihiko Izutsu dengan metode semantiknya ${ }^{31}$ dan Mohammed Arkoun dengan metode semiotiknya. ${ }^{32}$ Di Mesir, Amin Khuli (w. 1967), seorang dosen tafsir pada Universitas Mesir di Giza, juga mencoba merumuskan metode penafsiran yang menggarap aspek kebahasaannya. Ide-ide Amin Khuli ini dipaparkannya dalam tulisannya yang berjudul Manahij al-Tajdid yang selanjutnya direalisasikan oleh istrinya, 'Aisyah Abdurrahman yang dengan nama samaran Bintu Syati'dengan menulis kitab tafsir yang berjudul Al-Tafsiral-Bayani li Al-Qur'an al-Karim. ${ }^{33}$

\section{Hermeneutical: Memahami Konteks}

Penggalian terhadap makna teks yang hanya berhenti pada isi teks tanpa mau melihat konteks, yaitu latar belakang dan setting historis yang ada dibalik teks pada akhirnya hanya akan membawa pemahaman yang parsial dan penafsiran yang tidak tepat sasaran. Harus diakui, meskipun khazanah penafsiran Alquran biasdikatakan sangat kaya dengan karya, namun banyak penafsiran terhadap Alquran yang menafsirkan Alquran dengan "semena-mena" dan tanpamemperhatikan aspek historis yang melatarbelakangi munculnya teks yang bersangkutan. Bahkan seringkali penafsiran semacam ini dimaksudkan untuk membela pendirian atau maksud-maksud tertentu. Dalam kasus-kasus seperti penafsiran filosofis dan sufistis misalnya, gagasangagasan asing sering dipaksakan masuk kedalam Alquran tanpa memperhatikan konteks kesejarahan kitab suci itu. ${ }^{34}$

Langkah pertama dan utama dari penafsiran harus diakui adalah memahami dan menggali makna teks, tetapi dalam perspektif Hermeneutik langkah itu hanyalah awal, karena masih harus dilanjutkan dengan melihat konteks dari teks tersebut sebelum

${ }^{30}$ Lihat Abu Zakariyya Yahya ibn Ziyad al-Farra', Ma'ani Al-Qur'an, (Beirut: Dar al-Kutub al'Ilmiyyah, t.t.) 1966)

${ }^{31}$ Lihat Toshihiko Izutsu, Ethico Religius Concept in the Qur'an, (Montreal: McGill UniversityPress,

${ }^{32}$ Lihat antara lain dalam tulisan M. Arkoun, Kajian Kontemporer Al-Qur'an, terj. Hidayatullah,(Bandung: Pustaka, 1998)

${ }^{33}$ Issa J. Boullata, "Tafsir Al-Qur'an Moderen: Studi atas Metode Bintus Syati"” dalamAisyah Abdurrahman, Tafsir Bintusy-Syati', terj. Mudzakkir Abdussalam, (Bandung: Mizan, 1996), h. 12-13.

${ }^{34}$ Taufik Adnan Amal dan Syamsu Rijal Panggabean, Tafsir Konteksstual Al-Qur'an,(Bandung: Mizan, 1992), h. 16. 
merumuskan dan menentukan makna teks yang sebenarnya. Pemahaman terhadap konteks sejarah yang menjadi latar belakang munculnya ayat-ayat Alquran bisa dikatakan merupakan satu komponen vital untuk mengantarkan kepada pemahaman yang tepat terhadap Alquran. Apa yang menyebabkan Alquran itu turun dan bagaimana generasi yang mengalami langsung Alquran tersebut menyikapinya adalah poin utama yang tidak boleh ditinggalkan. Muhammad Shahrur dalam bukunya Al-Kitab wa AlQur'an: Qira'ah Mu'asirah berkata: “perlakukanlah Alquran seolah-olah Nabi baru meninggal kemarin". ${ }^{35}$ Urgensi dari perhatian terhadap konteks kesejarahan ini terletak pada realita bahwasanya sebagian besar muatan Alquran itu berkaitan dengan situasi keagamaan, keyakinan, pandangan dunia dan adat-istiadat masyarakat tempat ia turun, yaitu masyarakat Arab. Bukti yang sangat jelas mengenai asumsi ini adalah diturunkannya Alquran secara berangsur-angsur (tadarruj) selama 23 tahun masa kenabian Muhammad dan Fenomena nasikh dan mansukh ${ }^{36}$ dalam ayat-ayat Alquran. Disisi lain hal ini bisa dibuktikan misalnya dengan melihat bahwa ternyata di dalam Alquran banyak didapati nama dan peristiwa yang berkaitan dengan sejarah dan peristiwa-peristiwa tertentu yang merujuk kepada masa Nabi dan generasi awal muslim. Peristiwa Perang Badr, Uhud, juga nama-nama seperti Zaid, Abu Lahab; kasus khamr, perbudakan, perdebatan antara Nabi dan para penentangnya, dan lain sebagainya, adalah contoh yang jelas mengenai hal ini. ${ }^{37}$ Karena pentingnya perhatian terhadap konteks inilah banyak para pemikir moderen yang berusaha menggarapnya dengan serius. Fazlurrahman misalnya, dalam sebuah artikel yang ditulisnya pada tahun 1970, memberikan tiga patokan awal dalam penafsiran yang intinya adalah keharusan untuk memperhatikan konteks historis ayat-ayat Alquran. Ketiga rumusan tersebut adalah:

a. Untuk menemukan makna teks Alquran, suatu pendekatan historisharus digunakan, terutama terhadap ajaran-ajaran sosiologisnya. Alquran perlu dipelajari dalam tatanan kronologisnya agar diketahui perkembangan gagasangagasannya dan makna keseluruhan dari pesanAlquran yang sistematis dan koheren dapat diketahui.

b. Membedakan antara ketetapan-ketetapan legal dan tujuan-tujuan yangmenjadi maksud ketetapan legal tersebut.

c. Sasaran-sasaran Alquran harus dipahami dengan tetap memberperhatian terhadap latar belakang sosiologisnya, yakni lingkungandimana nabi bergerak dan bekerja. ${ }^{38}$

Pemahaman terhadap konteks kesejarahan ini pada akhirnya akanmembawa beberapa manfaat dalam penafsiran, seperti:

\footnotetext{
${ }^{35}$ Muhammad Shahrur, Al-Kitab wa Al-Qur'an: Qira'ah Mu'asirah, (Damaskus: Al-Ahly,1990), h.44.

${ }^{36}$ Nasikh biasa diartikan satu hukum syara' yang ditetapkan mengangkat (menghapuskan)hukum syara' yang lain yang ditetapkan sebelumnya; semantara mansukh adalah hukum syara' yang diangkat (dihapuskan) tersebut. Lihat antara lain dalam Manna' al-Qattan, Mabahis fi 'Ulum AlQur'an,(Beirut:Mu'assasah Risalah, 1993), h. 121.

${ }^{37}$ Taufik Adnan Amal dan Syamsu Rijal Panggabean, Tafsir Konteksstual..., h. 44.

${ }^{38}$ Fazlurrahman, Cita-cita Islam, terj. Suyanto (Yogyakarta: Pustaka Pelajar, 2000), h. 5254.
} 
1. Memudahkan dalam mengidentifikasi gejala-gejala moral dan socialmasyarakat Arab ketika itu, sikap Alquran terhadapnya, dan cara Alquran memodifikasi atau mentransformasi gejala tersebut sehinggasejalan dengan pandangan Alquran.

2. Menjadi pedoman bagi Umat Islam untuk mengidentifikasi danmenangani problem-problem yang mereka hadapi.

3. Terhindar dari praktek-praktek pemaksaan pra-konsepsi dalampenafsiran. ${ }^{39}$

Kesadaran akan pentingnya konteks sejarah dalam memahami ayatayatAlquran ini dalam ilmu tafsir Alquran sangat dikenal dalamdisiplin kajian Asbab an-Nuzul, ${ }^{40}$ dimana isi dari kajian ini adalah menelaah latar belakang diturunkannya ayat-ayat Alquran kepada Nabi. Disamping bertujuan untuk mengetahui latar belakang turunnya ayat Alquran,disiplin kajian ini pada akhirnya juga sangat membantu dalam melacakmakna dan spirit (semangat) dari suatu ayat, dimana hal ini tentunya sangat berguna dalam upaya kontekstualisasi ayat untuk waktu dan tempat yang berbeda. Menurut Abu Zayd, Ilmu Asbab al-Nuzul merupakan disiplin ilmu yang paling penting dalam menunjukkan hubungan dan dialektika antarateks dan realitas.

Ilmu tentang Asbab al-Nuzul memberikan bekal kepadaseorang mufassir mengenai materi teks yang merespon realitas, baikdengan cara menguatkan ataupun menolak, dan menegaskan hubunganyang dialogis dan dialektis antara teks dan realitas. ${ }^{41}$ Bahwa Asbab al-Nuzul merupakan salah satu bentuk dari perhatianterhadap konteks ayat, adalah sesuatu yang tidak bisa dibantah. Namun harus diketahui, yang dimaksud oleh Hermeneutika dengan konteks disinibukan sekedar peristiwa yang melatarbelakangi munculnya satu teks, tetapi lebih tepatnya adalah setting sosialhistoris dimana teks tersebut muncul. Perhatian terhadap konteks yang sekedar berhenti pada Asbab al-Nuzul seringkali membawa kelemahan. Kelemahan yang dimaksud misalnyasering hilangnya interaksi antara Asbab al-Nuzul dengan penafsiran, juga biasanya tidak kritis. Kutipan-kutipan mengenai Asbab al-Nuzul ini sering menimbulkan pengabaian terhadap konteks kesejarahan yangmelingkupinya, yakni setting socialhistorisnya.

Dengan melihat setting sosial-historis ini diharapkan dapat dilacakbagaimana masyarakat yang menjadi penerima teks tersebut memahamiteks yang dimaksud. Asumsi dasar dari pandangan ini adalah bahwasanya setting sosial-historis yang berbeda akan memunculkan pemahaman yang berbeda, sehingga seorang yang akan berbicara terhadap satu masyarakat kalau berkenaan dengan Alquran berarti Allahpastilah menyesuaikandengan kondisi masyarakat tersebut agar apa yang disampaikannya bisa dipahami secara tepat. Konteks dalam arti yang terakhir ini

\footnotetext{
${ }^{39}$ Taufik Adnan Amal dan Syamsu Rijal Panggabean, Tafsir Konteksstual..., h. 51.

${ }^{40}$ Asbab al-Nuzul dalam ilmu tafsir biasa didefinisikan sebagai "peristiwa yang karenanyaturun satu atau beberapa ayat Alquran yang isinya memuat atau menjawab peristiwa tersebut atau menjelaskan hukum dari peristiwa tersebut" Lihat antara lain Subhi al-Salih, Mabahis fi 'Ulum AlQur'an,(Beirut: Dar al-Malayin, 1988), h. 132.

${ }^{41}$ Nasr Abu Zayd, Mafhum al-Nass: Dirasat fi 'Ulum Al-Qur'an (Kairo: al-Hay'ah al-Misriyyah al'Ammah li al-Kitab, 1993), h. 119.
} 
setidaknya menuntut adanya ketrampilan dalam ilmu sosiologi dan antropologi. Dan dengan kerangka berpikir yang berlandaskan konteks ini akhirnya akan terasa wajar jika dalam Alquran banyak ditemukan contoh-contoh yang secara spesifik dikenal di wilayah Arab, seperti sebuah peringatan dengan penciptaanunta dalam Surat AlGasiyah atau keindahan surga yang digambarkan dengan mengalirnya sungai di bawahnya. Semua itu tentunya gambaran kondisi masyarakat Arab yang kesehariannya akrab dengan unta dan hanya bias membayangkan indahnya sungai dan air yang mengalir. Pelacakan terhadap konteks historis ini bisa dikatakan merupakan ciri yang paling menonjol dari Hermeneutika Moderen.

Sejak dipopulerkannya kembali Hermeneutika oleh Schleiermacher sebagai sebuah metode penafsiran yang paling memadai dalam menghadapi teks-teks suci, halyang pertama yang dicanangkan oleh Schleiermacher yang dijuluki "Bapak Hermeneutika Moderen" adalah memperhatikan konteks historis tempat teks itu muncul.Kebanyakan penafsiran tidak memperhatikan aspek ini. Sebagianbesar penafsiran dilandaskan kepada asumsi bahwa satu teks tertulis itu memiliki "kehidupan"-nya sendiri dan terbebas dari "sang pengarang"-nya, dimana untuk memahaminya hanya perlu sedikit, atau bahkan tidak perlusama sekali memahami maksud dan tujuan pengarang saat menulisnya.

\section{Hermeneutical: Mengupayakan Kontekstualisasi}

Pemahaman akan Alquran dalam konteksnya sebagaimana dipaparkan diatas, akan menjadi kajian yang semata-mata bersifat akademis murni bila tidak diproyeksikan untuk memenuhi kebutuhan-kebutuhan kontemporer. ${ }^{42}$ Disinilah perlunya kontekstualisasi, dalam arti upaya untuk menerapkan makna teks yang dipahami dari suatu wacana dalam kontek tertentu di masa yang telah lalu dengan konteks yang berbeda di masakini. Dalam bahasa Fazlurrahman, seorang penafsir harus melakukan double movements atau gerakan ganda, yaitu merumuskan visi Quran yang utuh dan kemudian menerapkan prinsip umum tersebut dalam situasi sekarang. ${ }^{43}$ Setidaknya ada dua asumsi dasar yang menjadi latar belakang perlunyakontekstualisasi ini, yaitu:

a. Alquran adalah dokumen untuk manusia. Ia menyebut dirinyasebagai petunjuk bagi manusiahudan li al-nasserta berbagai julukan lain yang senada. Sebagai dokumen untuk manusia, Alquran harusselalu dapat memberikan bimbingan kepada manusia dalam hidup dankehidupan mereka. Dengan kata lain Alquran merupakan sumberdan tata nilai mereka. ${ }^{44}$

b. Sebagai petunjuk Allah yang jelas berkaitan bagi manusia, pesan-pesan Alquran bersifat universal; dan ini disepakati oleh seluruh umat Islam. ${ }^{45}$ Persoalannya

\footnotetext{
${ }^{42}$ Taufik Adnan Amal dan Syamsu Rijal Panggabean, Tafsir Konteksstual..., h. 61.

${ }^{43}$ Taufik Adnan Amal, Metode dan Alternatif ..., h. 33.

${ }^{44}$ Ibid., h. 34.

${ }^{45}$ Ibid., h. 38 .
} 
kemudian adalah bagaimana agar pesan-pesanAlquran yang universal itu bisa ditangkap dan dianfaatkan olehsetiap orang pada setiap masa.

Dalam diskursus Ilmu tafsir Alquran, tema kontekstualisasi ini cukup mendapat perhatian dan sering menjadi bahan diskusi. Hal ini tidak mengherankan, disamping karena kebutuhan umat Islam untukmerujuk kepada Alquran yang merupakan pedoman pertama dan utamabagi mereka dalam berbagai aspek kehidupan, tafsir yang kontekstual itutentunya akan menjadi bukti bahwasanya Alquran memang benarbenar"sesuai pada setiap tempat dan masa".Betapapun tidak mudah untuk melaksanakan ideal kontekstualisasiAlquran tersebut, dalam khazanah kepustakaan muslim telah banyakmuncul kitab-kitab tafsir Alquran dengan tokoh dan ciri khasnya yang berusaha untuk memahami Alquran secara kontekstual. Muatan tafsir dengan corak ini biasanya ditujukan untukmengedepankan petunjuk Alquran dan ajaranajarannya yang dengannyadapat diperoleh kebahagiaan dunia dan akhirat.Tafsir jenis ini padadasarnya ingin agar petunjuk-petunjuk dari Alquran itu bisa digali dandimanfaatkan secara operasional oleh umat Islam dalam kehidupan nyatadi dunia ini. ${ }^{46}$ Menurut J.M.S. Baljon, tafsir semacam inilah yang biasdisebut sebagai tafsir moderen. ${ }^{47}$ Kontekstualisasi berarti melihat realitas historis yang sedang terjadipada saat ini dan kemudian mencari pedoman dan petunjuk Alquranmengenai apa yang harus dilakukan. Disinilah sebenarnya inti dari operasiHermeneutika. Dalam bahasa Dilthey, Hermeneutika berarti menafsirkansecara reproduktif, dalam arti tidak sekedar mencari pemahaman apa yangdimaksud oleh teks semata, tetapi juga mencari apakah teks bermaknauntuk masa kini. ${ }^{48}$ Menurut Dilthey, satu peristiwa itu, termasuk peristiwamunculnya teks, dapat dipahami dengan tiga proses:

a. Memahami sudut pandang atau gagasan para pelaku asli.

b. Memahami arti atau makna kegiatan-kegiatan mereka yang secaralangsung berhubungan dengan peristiwa sejarah.

c. Menilai peristiwa-peristiwa tersebut berdasarkan gagasan yang berlakupada saat sejarawan yang bersangkutan hidup. ${ }^{49}$

Senada dengan pandangan Dilthey tersebut, Carl Braatenberpandangan bahwa berusaha memahami suatu teks berarti mencobamemahami horizon zaman yang berbeda untuk dipahami dan diwujudkan dalam situasi konteks masa kini. ${ }^{50}$

\section{Hermeneutika Via Alquran}

Ilmu Tafsir adalah ilmu yang lahir dari kebutuhan kaum muslimin untuk memahami kandungan alquran.Ilmu ini telah lahir sejak generasi awal tabi'in dan terus

\footnotetext{
${ }^{46}$ Corak tafsir semacam ini-dengan segala karakter dan ciri khasnya dalam ilmu Al-Qur'an biasa disebut dengan Tafsir al-Adab al-Ijtima'i. Muhammad Husein Al-dahabi, Al-Tafsir Waal-Mufassirun, (Beirut: Dar Al-Fikr), Juz II, h. 457.

${ }^{47}$ J.M.S. Baljon, Tafsir Qur'an Muslim Modern, terj. Niamullah Muis, (Jakarta: PustakaFirdaus, 1994), h. 2.

${ }^{48}$ Richard E. Palmer, Hermeneutics...,h.68.

${ }^{49}$ Ibid.,h. 62.

${ }^{50}$ Carl Braaten, History and hermeneutics (Philadelpia: Fortress, 1966), h. 131.
} 
menerus mengalami penyempurnaan. Pada abad ke-2 $\mathrm{H}$ ilmu ini telah sampai ke tahapnya yang sempurna, sehingga telah dianggap sebagai ilmu yang baku yang harus digunakan oleh setiap mufassir yang datang kemudian. Didalam kitabnya al Itqan Zarkasyi menerangkan, bahwa ilmu tafsir adalah ilmu yang berguna untuk mengungkap makna-makna yang dikandung alquran, menjelaskan makna-maknanya dan mengeluarkan hukum-hukum serta hikmah yang dikandungnya. ${ }^{51} \mathrm{Jika}$ kita melihat pengertian ilmu Tafsir di atas serta pengertian Hermeneutika sebelumnya kedua ilmu ini sama-sama membahas tentang makna pada teks. Hanya saja ilmu Tafsir khusus digunakan untuk memahami kandungan makna teks alquran. Mengenai bisakah Hermeneutika digunakan untuk menafsirkan alquran? Jawaban atas masalah ini merupakan topik inti dalam tulisan ini.

Setelah mengamati berbagai tulisan dan pandangan para cendekiawan muslim minimal ada dua pendapat atas masalah tersebut: Pertama, Hermeneutika tidak bisa digunakan untuk menafsirkan alquran. Hermeneutika lahir dan berkembang dari suatu peradaban dan pandangan hidup masyarakat penemunya.Setiap ilmu, konsep atau teori termasuk Hermeneutika, pasti merupakan produk dari masyarakat, atau bangsa yang memiliki peradaban dan pandangan hidup sendiri.Pendapat ini dianut oleh sebagian besar mufassir. Beberapa cendekiawan, seperti Alparslam, Hamid Fahmy, Anis Malik Toha, dan Wan Moh Nor sejalan dengan faham di atas. Alparslan salah seorang cendekiawan Turki berpendapat, "Pandangan hidup setiap peradaban merupakan kumpulan dari konsepkonsep yang dalam konteks keilmuan berkembang menjadi tradisi ilmiah (scientifik tradition). ${ }^{52}$ Tradisi ilmiah pada gilirannya menghasilkan berbagai disiplin ilmu, seperti yang kita lihat sekarang, termasuk teori atau konsep Hermeneutika. Karena ilmu dilahirkan oleh pandangan hidup maka ia memiliki presupposisi sendiri dalam bidang etika, ontologi, cosmologi dan metafisika. Hal-hal inilah yang menjadikan ilmu (khususnya ilmu-ilmu sosial), termasuk Hermeneutika tidak netral. Untuk memperkuat pendapatnya, ia mengutip pendapat salah seorang pakar Hermeneutika Werner G.Jeanrond.

Ada tiga milleu penting yang berpengaruh terhadap timbulnya Hermeneutika sebagai suatu metode, konsep atau teori interpretasi. Pertama milleu masyarakat yang terpengaruh oleh pemikiran Yunani. Kedua milleu masyarakat Yahudi dan Nasrani yang menghadapi masalah teks kitab suci mereka dan berupaya untuk mencari model yang cocok untuk interpretasi. Ketiga masyarakat Eropa di zaman Enlightenment yang berusaha lepas dari tradisi dan otoritas keagamaan dan membawa Hermeneutika keluar dari konteks keagamaan. Selain itu, Epistemologi dalam Islam berbeda dengan epistemologi barat. Dalam Islam sumber inspirasi tidak hanya akal. Karena akal manusia mempunyai keterbatasan. ${ }^{53}$ Alquran banyak menyebutkan peristiwa yang tidak bisa diterima oleh akal. Dan hal ini tidak pernah terlintas dalam pemikiran para pakar Hermeneutika. Misalnya ceritera kapalnya nabi Nuh, nabi Ibrahim yang tidak mempan

${ }^{51}$ Zarkasy, al Itqan fi 'Ulumil Quran, (Darul Fikri : Beirut, t.t), h. 174.

${ }^{52}$ Alparslan Acikgence,Islamic Science,Toward Definition, (Kualalumpur:ISTAC,1996), h.29.

${ }^{53}$ Werner,G Jeanrond, Theological Hermeneutic, Development andSignificantce, (London; Macmillan, 1991), h. 12-13. 
dibakar, nabi Musa yang dapat membelah laut, Isra dan mi'rajnya nabi Muhammad saw,.dan banyak lagi. Peristiwa-peristiwa tersebut bukanlah khayalan akan tetapi merupakan khabar shadiq (benar dan tidak diragukan lagi).

Selain itu pula jika ilmu pengetahuan berdasarkan pada kepentingan individubaik bersifat politik, ekonomis maupun idiologi maka pengetahuan itu tidak dapat diaplikasikan untuk kepentingan individu lain. Apatah lagi diaplikasikan untuk menjelaskan maknamakna ajaran dalam alquran.Memahami alquran dengan metode Habermas misalnya, justru mereduksi ayat-ayat alquran kedalam makna-makna individu.Dalam Islam wahyu (revelation) menempati posisi penting. Rasio an sich sebagai sumber inspirasi seperti pendapatnya Habermas berbeda dengan Islam yang menempatkan wahyu dan rasio sekaligus yang berfungsi sebagai sumber dan penjelas termasuk juga ilmu pengetahuan. Disinilah letakperbedaan epistemologi Hermeneutika Kritis dan Islam. ${ }^{54}$ Kedua, hermeneutika adalah pengetahuan yang membahas penafsiran dari suatu teks.Teks tersebut meliputi berbagai teks yang merupakan produk ekspresi manusia.Menurut Komaruddin hermeneutika memiliki banyak persamaan dengan ilmu tafsir yang sudah dikenal sejak abad pertama hijriyah. Walaupun hermeneutika lahir dari masyarakat tertentu yang berbeda dengan masyarakat yang memunculkan ilmu tafsir, akan tetapi sebagai ilmu ia bisa digunakan, tentunya dengan penyesuaian-penyesuaian tertentu. Suatu peradaban bisa saja mengimport suatu konsep, tentunya dengan proses modifikasi konseptual atau apa yang disebut borrowing proses. ${ }^{55}$

Jika modifikasi konsep ini melibatkan konsep-konsep dasar yang lebih utama maka perubahan paradigma (Paradigma Shift) tidak dapat dielakkan.Selain itu juga, Implementasi Hermeneutika dalam Islam berbeda dengan Hermeneutika dalam dunia Kristen. Implementasi Hermeneutika dalam dunia Kristen digunakan untuk mencari orsinialitas kitab suci mereka.Mereka menemukan teks kitab suci yang sangat beragam, sehingga mereka perlu mencari mana dari semua itu yang asli dan paling benar. Sedangkan penggunaan Hermeneutika dalam dunia keilmuwan Islam digunakan bukan untuk mencari keotentikan teks alquran, akan tetapi untuk mencari penafsiran yang paling mendekati kebenaran. Dan kebenaran dari suatu tafsir hanya Allah yang mengetahui (sehingga seorang mufassir sehebat apapun akan berkata Wallahu a'lam).

\section{Penutup}

Harus diakui bahwa hermeneutika memang menawarkan sesuatu yang sangat menarik dalam wacana penafsiran kitab suci. Pola penafsiran yang ditawarkannya di satu sisi mengungkap asumsi-asumsi metodologisyang 'manusiawi' karena tidak hanya memperhatikan isi teks, tetapi jugamempertimbangkan keberadaan konteks yang melingkupi teks tersebut,baik konteks psikologis maupun konteks sosial. Di sisi lain, hermeneutikamembuka jalan bagi upaya kontekstualisasi kitab suci sehingga dapat

\footnotetext{
${ }^{54}$ Malki Ahmad Nasir, "Hermeutika Kritis (Studi Kritis atas Pemikiran Habermas)" dalam Jurnal Islamia Thn. I No.I,(Jakarta: Khairul Bayan, 2004), h. 36.

${ }^{55}$ Komaruddin Hidayat,Memahami Bahasa Agama: Sebuah Kajian Hermeneutika, (Jakarta: Paramadina, 1996), h. 126.
} 
berdialog dan operasionaln fungsional dalam berbagai ruang dan waktuyang berbeda, sebagaimana yang diidamkan dan dipegangi secara apologisoleh banyak kalangan Umat beragama terhadap kitab sucinya masing-masing. Meskipun wacana hermeneutika sendiri harus dikatakan sangat pluraldan beragam, baik dari aspek tokoh-tokohnya maupun dari segi pola-pola aplikasinya, tetapi secara umum hermeneutika tidak pernah melepaskan diri dari ketiga komponen pokoknya, yaitu teks, konteks dan kontekstualisasiyang diidealkan beroperasi secara sinergis dalam memahami, menafsirkan sekaligus melakukan produksi makna baru sesuai dengan realitas ruang dan waktu kontekstual, khususnya ketika diaplikasikan sebagai mediauntuk memahami kitab suci.

Selain sumbangan pemahaman yang komprehensif denganmenimbang dimensi konteks dan secara aktif melakukan kontekstualisasi, hermeneutika menyumbangkan sebuah kesadaran yang sangat vital dalamkehidupan sosial manusia, yaitu kesadaran akan pluralitas. Kesadaranbahwa realitas kehidupan tidak pernah tunggal dan satu dimensi, namunsenantiasa multi-dimensi dapat dikatakan merupakan kesadaran yangsangat diperlukan di era globalisasi informasi saat ini. Tidak ada orangyang bisa hidup tanpa berinteraksi dan bersinggungan dengan yang lain.Ketidakmampuan untuk mengapresiasi dan mengakui yang lain hanyaakan membawa seseorang terasing dari realitas hidupnya sendiri. Dititik inilah hermeneutika menemukan relevansinya dengan tawarannyauntuk menimbang pluralitas dalam konteks dan progresifitas dalamkontekstualisasi ketika seseorang melakukan aktifitas pemahaman danpenafsiran. 


\section{DAFTAR PUSTAKA}

Abu Zayd, Nasr. Mafhum al-Nass: Dirasat fi 'Ulum Al-Qur'an, Kairo: al-Hay'ah alMisriyyah al-'Ammah li al-Kitab, 1993.

Ahmad Nasir, Malki. " Hermeutika Kritis (Studi Kritis atas Pemikiran Habermas)" dalam Jurnal Islamia Thn. I No.I, Jakarta: Khairul Bayan, 2004.

Ahmad Nasir, Malki. 2004 "Hermeutika Kritis (Studi Kritis atas PemikiranHabermas)" dalam Jurnal Islamia Thn. I No.I Jakarta: Khairul Bayan.

Alparslan Acikgence,Islamic Science, Toward Definition, Kualalumpur:IST AC,1996.

al-Suyuti, Jalal al-Din.Al-Itqan fi 'Ulum Al-Qur'an, Beirut: Dar al-Fikr, t.t.

Arkoun, M. Kajian Kontemporer Al-Qur'an, terj. Hidayatullah,Bandung: Pustaka, 1998.

Braaten, Carl.History and hermeneutics, Philadelpia: Fortress, 1966.

Daniel Parera, Jos.Leksikon Istilah Pembelajaran Bahasa, Jakarta: PT. Gramedia PustakaUtama, 1993.

Eliade, Mircea.The Encyclopedia of Religion, New York: Macmillan, 1993.

Esack, Farid.Qur'an: Liberation \& Pluralism, Oxford: One World, 1997.

Fazlurrahman, Cita-cita Islam, terj. Suyanto, Yogyakarta: Pustaka Pelajar, 2000. , Islam dan Modernitas, terj. Ahsin Muhammad, Bandung: Pustaka, 1985.

Hanafi, Hasan.Dialog Agama dan Revolusi, terj. Pustaka Firdaus, Jakarta: Pustaka Firdaus, 1994. .Muqaddimah fi 'Ilm al-Istighrab, Kairo: Dar al-Faniyah, 1991.

Hidayat, Komaruddin.Memahami Bahasa Agama: Sebuah Kajian Hermeneutika,Jakarta: Paramadina, 1996.

Issa J. Boullata, "Tafsir Al-Qur'an Moderen: Studi atas Metode Bintus Syati"" dalamAisyah Abdurrahman, Tafsir Bintusy-Syati', terj. Mudzakkir Abdussalam, Bandung: Mizan, 1996.

J.M.S. Baljon, Tafsir Qur'an Muslim Modern, terj. Niamullah Muis, Jakarta: PustakaFirdaus, 1994.

Jane Mc Mauliffe, “Qur'anic Hermeneutics: The Views of Al-tabari and The Ibn Katsir" dalam A. Rippin (ed.), Approaches to the History of the Qur'an, (Oxford: Clarendon, 1988.

Mur Ichwan, Moch. “Al-Qur'an sebagai Teks: Teori Teks dalam Hermeneutik AlQur'anNasr Abu Zayd” dalam Esensia, Vol. 2, No.1, 2001.

Nabilah Lubis, Naskah, Teks dan Metode Penelitian Filologi, Jakarta: Forum Kajian Bahasadan Sastra Arab Fakultas Adab IAIN syarif Hidayatullah, 1996.

Nanji, Azim. "Toward a Hermeneutic of Qur'anic and Other Narratives of Isma'iliThought" dalam Richard C.martin (ed.), Approaches to Islam in Religious Studies Tucson: TheUniversity of Arizona Press.

Nasr Hamid Abu Zayd, Isykaliyat al-Qira'at wa 'Aliyat al-Ta'wil,Beirut: al-Markaz alSaqafi al-'Arabi, 1994. 
Shahrur, Muhammad.Al-Kitab wa Al-Qur'an: Qira'ah Mu'asirah, Damaskus: AlAhly,1990.

Sudarto, Metodologi Penelitian Filsafat, Jakarta: PT. Raja Grafindo Persada, 1996.

Taufik Adnan Amal dan Syamsu Rijal Panggabean, Tafsir Konteksstual AlQur'an,Bandung: Mizan, 1992.

Toshihiko Izutsu, Ethico Religius Concept in the Qur'an, Montreal: McGill UniversityPress, 1966.

Van A. Harvey, "Hermeneutics" dalam Eliade, Mircea (ed.), Encyclopedia of Religion, London: MacMillan, 1986.

Werner,G Jeanrond, Theological Hermeneutic, Development andSignificantce, London; Macmillan, 1991.

Zakariyya Yahya ibn Ziyad al-Farra', Abu. Ma'ani Al-Qur'an, Beirut: Dar al-Kutub al'Ilmiyyah, t.t.

Zarkasy,al Itqan fi 'Ulumil Quran, Darul Fikri : Beirut, t.t. 